\title{
Bacterial leakage around dental restorations: its effect on the dental pulp
}

\author{
G. Bergenholtz*, C. F. Cox**, W. J. Loesche** and S. A. Syed*** \\ * Faculty of Odentology, Gothenburg University, Sweden and * Laboratories of Oral Histology and \\ Microbiology, Department of Oral Biology, The University of Michigan School of Dentistry, Ann \\ Arbor, USA
}

\begin{abstract}
This study revealed that the quantity of bacteria filtered from the base of Class V cavity restorations were directly related to the type of medicament used. Of the brands studied: composite, amalgam, silicate, and guttapercha - each produced varying numbers of bacterial colonies, whereas zinc oxide and eugenol cement showed none. Histopathology of the pulps correlated directly to the microbiological data.
\end{abstract}

Accepted for publication July 7, 1982

Much effort has been spent evaluating pulpal compatability of dental restorative materials (Frank 1976). The materials are generally tested in cavities prepared in dentin of healthy animal teeth and the pulp tissue reactions histologically observed after various time periods, according to the guidelines of the American National Standards Committee MD 156. (1978) for Dental Materials and Devices. The many inherent variables make distinction difficult between the irritant effect of the material and other influences, such as cavity preparation trauma and/or marginal leakage. In recent years, attention has been focused upon the effects of microbial irritants. Several investigators, (Brännström 1971, Brännström \& Nyborg 1971, 1973, 1974, Brännström \& Vojinovic 1976, Hansen \& Bruun 1971, Dickey et al. 1974, Qvist 1975), utilizing bacterial staining techniques in histological sections, have observed a relationship between pulp tissue inflammation and the presence of stainable bacteria on the dentin floor and in the cut tubules beneath the filling. Recently, Mejàre et al. (1979) recovered bacteria similar to those of aging dental plaque from the interface between unlined composite restorations and the cavity floor.

Animal experiments have confirmed that bacterial contamination of exposed dentin may play an important role in pulpal disease. After freshly cut dentin in monkeys was exposed to either an extract of human dental plaque (Bergenholtz \& Lindhe, 1975), or components of cultivated dental plaque bacteria (Bergenholtz 1977, Bergenholtz \& Warfvinge 1982), an acute inflammation, characterized by increased vascular permeability and migration of leukocytes, appeared in the pulp underneath the cut tubules within a period of $8-32 \mathrm{~h}$. Similar results in experimentally immunized monkeys, followed pro- 
vocation of the cut dentin with an immunogen (Bergenholtz et al. 1977). Thus, normal dentin, freshly cut by rotating instruments, is unable to protect the underlying pulp from bacterial irritation.

The present study assesses the relationship of bacterial contamination to pulpal irritation beneath various dental restorative materials, and specificially: (1) the ability of some permanent and temporary filling materials to accomplish a bacteria-tight seal of Class $\mathrm{V}$ cavities in monkey teeth, (2) to correlate the histopathology of the pulp with the presence or absence of cultivable bacteria.

\section{Material and methods}

Experimental procedure. Four adult rhesus monkeys (macaca mulatta) with permanent dentitions were used. The following test materials: Dispersalloy amalgam*; Concise composite resin†; Hygienic guttapercha†; MQ silicate cements§; zinc oxide and eugenol (ZOE)// were employed in random distribution over 20-24 teeth in each monkey. During operative procedures the animals were intramuscularly sedated with Ketamine $\gamma$ hydrochloride $(100 \mathrm{mg} / \mathrm{cc})$ supplemented when necessary with intravenous injections of sodium pentobarbital ${ }^{\infty 0}(25 \mathrm{mg} / \mathrm{cc})$.

* Johnson \& Johnson, East Windsor, N.J. U.S.A. 08561, Code No. 2836.

$\dagger 3$ M, St. Paul, Minn. U.S.A. 55102, Batch Nos. 1994A, 1994B.

† Hygienic Dental Mgf. Co., Akron. Ohio, U.S.A. 44308, Batch No. 07424.

$\S$ S. S. White, Philadelphia, Penn. U.S.A. 19107, Batch No. 1666602.

// U.S.P., J. T. Baker Chemical Co., Phillipsburg, N.J. 08865.

$\gamma$ Ketalar, Park-Davis \& Co., Detroit, Mich. U.S.A. 48230.

œ Sodium Pentobarbitol, Batch No. 04148011, The University of Michigan Hospital Pharmacy, Ann Arbor, Mi. U.S.A. 48109.
Three weeks prior to commencement, the complete dentition of each monkey was meticulously scaled and polished with pumice in a rubber cup. The teeth were subsequently toothbrushed three times a week to maintain gingival health and a topical application of $0.2 \%$ chlorhexidine-digluconate ${ }^{\circledR}$ was employed. Toothbrushing was repeated on the day of placement but without topical application of chlorhexidine. Sequences of 2-3 teeth were simultaneously isolated with a rubber dam held in place by dental tape ligatures, disinfected by hydrogen peroxide $(30 \%)$ and iodine tincture (5\%). A sterile \#35 inverted, carbide cone bur was used to prepare a buccal Class V cavity in each tooth. The enamel was penetrated on the buccal surface $1 \mathrm{~mm}$ above the gingival margin. Dentinal cavities were prepared under constant irrigation with sterile saline at low speed, and the depth adjusted such that approximately $0.5 \mathrm{~mm}$ of dentin was left in each tooth. In three of the four monkeys, a solution of $0.5 \mathrm{M}$ EDTA was applied in the cavity for $1 \mathrm{~min}$. for cleansing purposes and then flushed with sterile saline and dried by evacuation (Leidahl \& Eriksen 1979).

As a sterility control at the completition of each cavity, the blunt end of a sterile endodontic paper point was inserted in the cavity to absorb moisture and any possible micro-organisms, and immediately placed in a tube containing basal anaerobic broth. The tube was placed in an anaerobic glove box\# (Aranki et al. 1969), and the presence or absence of bacterial growth was determined after 7 days of anaerobic incubation at $37^{\circ} \mathrm{C}$.

A $0.3 \mathrm{~mm}$ thick, sterile filter-paper** disk of $1 \mathrm{~mm}$ diameter was placed at the bottom of

- Chlorhexidine 20\% W/V. Stuart Pharmaceuticals. Division of I.C.I., United States Inc., Wilmington, Del. U.S.A. 19897.

\# Coy Laboratory Products, Ann Arbor, Michigan U.S.A. 48104.

** W. R. Balston, Ltd. London, England. 


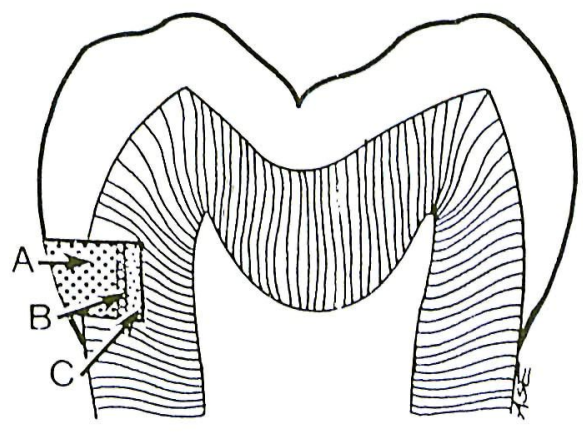

Fig. 1. Typical treatment for each tooth: (A) is the area filled with one of the 5 restoratives; $(B)$ the .3 $\times 10 \mu \mathrm{m}$ Teflon disc; $(\mathrm{C})$ the $.1 \times 10 \mu \mathrm{m}$ sterile filter-paper disc.

the cavity to collect bacteria. Before insertion of the test material, a $0.1 \mathrm{~mm}$ thick Teflon ${ }^{++}$ disk was placed over the paper disk (Fig. 1) to separate it from direct contact with the restoration and to facilitate recovery of the filter at termination.

Cavities restored with Concise ${ }^{\circledR}$ were prepared through the enamel into the dentin and then acid etched with $50 \%$ phosphoric acid for $1 \mathrm{~min}$ at the internal enamel wall and external cavity margins, then flushed with saline and dried. The pulpal floor of the cavity was further deepened to approximately $0.5 \mathrm{~mm}$ of the remaining dentin, and not etched. A layer of Concise ${ }^{\circledR}$ enamel bonding agent was placed on the cavity margins before insertion of Concise ${ }^{\circledR}$. A plastic Mylar ${ }^{\circledR}$ strip was used to compress the composite material during polymerization.

The amalgam, silicate, and composite materials were each mixed according to the manufacturer's recommendations and inserted into the designated cavity. Each silicate cement filling was greased with a sterile surgical

$\dagger \dagger$ Habia Co., Sweden.
Table 1.

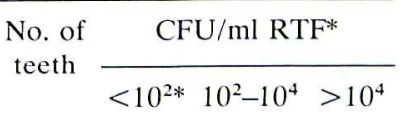

Composite resin

2-3 weeks

8 weeks

$\begin{array}{rrrr}11 & 7 & 1 & 3 \\ 8 & 5 & 1 & 2\end{array}$

Amalgam

2-3 weeks

8 weeks

$\begin{array}{llll}8 & 4 & 2 & 2 \\ 8 & 0 & 2 & 6\end{array}$

Silicate

2-3 weeks

8 weeks

$\begin{array}{llll}6 & 0 & 1 & 5 \\ 6 & 0 & 2 & 4\end{array}$

Guttapercha

2-3 weeks

8 weeks

Zinc oxide-eugenol

2-3 weeks

8 weeks

$\begin{array}{llll}6 & 4 & 0 & 2 \\ 7 & 5 & 1 & 1\end{array}$

Bacterial growth from filter-paper disks. ${ }^{*}<10^{2}$ colony-forming units ( $\mathrm{CFU}$ ) denotes no detectable growth.

* RTF = transport medium (Syed \& Loesche 1972).

lubricant Lubafax ${ }^{\circledR} \dagger \dagger$ immediately upon completion. ZOE was pre-mixed to a pastelike consistency, covered until needed, the excess eugenol being squeezed out before placement. The guttapercha was disinfected in $5 \%$ sodium hypochlorite for $2 \mathrm{~min}$ immediately prior to placement, rinsed in sterile saline, and softened by the heated metal sterile instrument with which it was inserted into the test cavity.

The experiment was scheduled for two observation periods per animal: $2-3$ weeks and 8 weeks after placement of restorations. The distribution of the materials for the different periods is given in Table 1 .

At completion, the teeth were brushed,

$\dagger \neq$ Burroughs Wellcome \& Co., Tuckahoe, New York 10707. 
polished, and isolated with a rubber dam, and disinfected as before. A surface layer of enamel surrounding each cavity was removed together with the restorative material, using a slow running sterile bur without water spray and the enamel debris transferred with a sterile paper point to a basal anaerobic broth tube for sterility control. The filling was then carefully removed together with the Teflon and filter disks and the latter was placed in a vial containing $5 \mathrm{ml}$ of an RTF transport medium (Syed \& Loesche 1972). The vial was inserted in the anaerobic glove box for microbiological analysis.

Microbiological analysis. In the anaerobic glove box each sample was dispersed for $20 \mathrm{~s}$ by sonication with an ultrasonic disrupter ${ }^{++}$ followed by Vortex mixing for $15 \mathrm{~s}$. The dispersed sample was automatically plated on Enriched Trypticase Soy Agar (ETSA) plates $^{0000}$ using a spiral plater. After 7 days of anaerobic cultivation the plates were read and the number of colony-forming units (CFU) of bacteria was determined with the aid of a quadrant device (Loesche \& Straffon 1979). $\log ^{10}$ transformations of absolute values were performed. Since the samples were dispersed in $5 \mathrm{ml}$ of RTF, no less than 100 bacterial colonies could be detected by this method. Identifications of bacteria were made according to colony morphology and Gram stain.

Histological analysis. Seven $\mu \mathrm{m}$ serial sections from paraffin-embedded, EDTA-demineralized teeth were made in a buccolingual-axial direction through the cavity preparation of each tooth. Alternate slides containing 10-12 sections were stained either with hematoxylin-eosin, or a bacterial-detection stain (Brown \& Brenn 1931). The Brown

\footnotetext{
++ Kontes Co., Vineland, N.J. U.S.A. 98360.

wow The University of Michigan Bacteriology Laboratory, Ann Arbor, MI. U.S.A. 48109.
}

\& Brenn technique was controlled on smears for Gram-positive (Actinomyces viscosus, Streptococcus sanguis) and Gram-negative (Fusobacterium nucleatum, Bacteroides gingivalis) bacteria. Gram-positive bacteria stained adequately, but Gram-negative bacteria did not stain effectively with the recommended formula.

Response was Grade 1 if no bacteria were observed in the cavity preparation or in any of the cut tubules, Grade 2 for a positive reaction in limited areas of the walls and the axial floor of the cavity preparation and Grade 3 when large numbers of bacteria were detected on either the cavity walls or within many of the cut tubules.

The histology was separately evaluated on a double-blind system by two reviewers having no knowledge of the tissues, restorative materials, or microbiological findings and in cases of difference between the reviewers, tissue was reassessed and a concensus reached. The following criteria for histological assessment were used: Grade 1 inflammatory-cell response was characterized by a normal pulp without any inflammatory cells present, a few scattered mononuclear leukocytes were possibly present in the deeper portions of the pulp tissue (Fig. 2); Grade 2 presented a mild leukocytic infiltrate of polymorphonuclear leukocytes (PMN's) and/or mononuclear leukocytes within the odontoblastic region (Fig. 3) subjacent to the cut dentinal tubules; Grade 3 showed a definitive leukocytic infiltrate in the pulp below the cut tubules of the cavity, seen either as localized aggregates of mononuclear leukocytes throughout several serial tissue sections and/or PMN's in one to several cell layers; Grade 4 presented either abscess formation, adjacent to the cut tubules of the cavity seen after the $2 / 3$-week period (Fig. 4), or a dense infiltrate of mononuclear leukocytes throughout most of the coronal pulp at the 8-week interval.

Measurement of the remaining dentin 


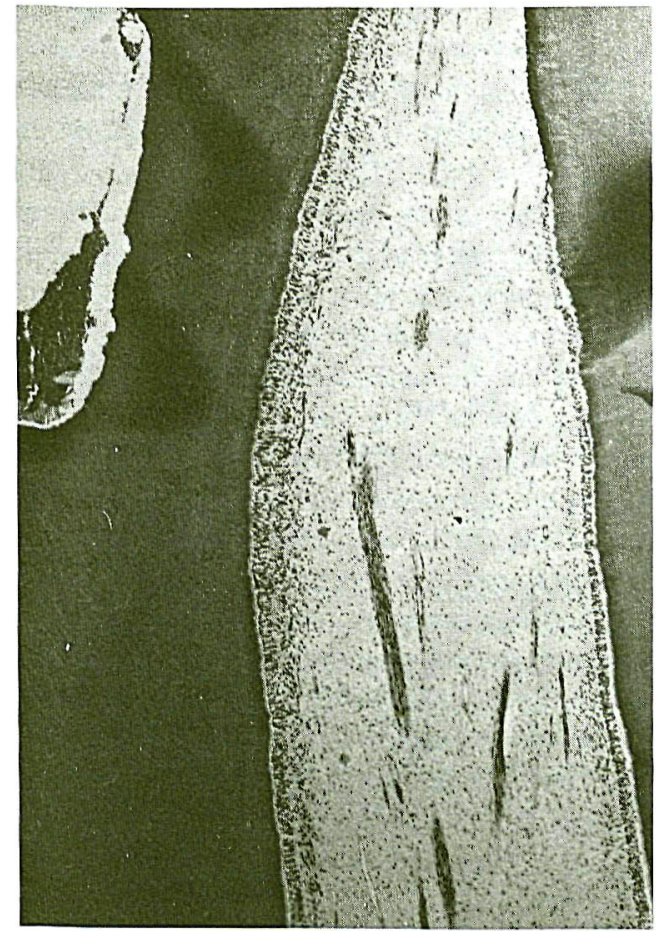

Fig. 2. Grade 1 inflammatory response of dental pulp 3 weeks after ZOE placement. Note the pulp and odontoblastic layer is without inflammation. Orig. mag. $25 \times$

between the cavity bottom and the pulp was performed with a calibrated eyepiece along the dentinal tubules. Reparative dentin formation was observed below the cut tubules and measured either as a small thin rim of new dentin or a large bulk of increased thick reparative dentin.

Statistical analysis. The bacterial and histological data were analyzed by Chi square, Kruskal-Wallis, and by Analysis of Variance (ANOVA) tests. Differences between groups within ANOVA were compared using the Scheffe test. All statistical tests were performed using the Michigan Interactive Data
Analyses System (MIDAS) at The University of Michigan Computing Center.

\section{Results}

Microbiological analysis. Sterility controls showed growth in 8 of 79 teeth, with grampositive cocci (streptococci) being most frequent, and of these 8 , subsequent culturing of filters at 3 and 8 weeks showed that anaerobic bacteria could only be cultivated from 2 of the 8 retrieved filter-paper disks. Sterility controls

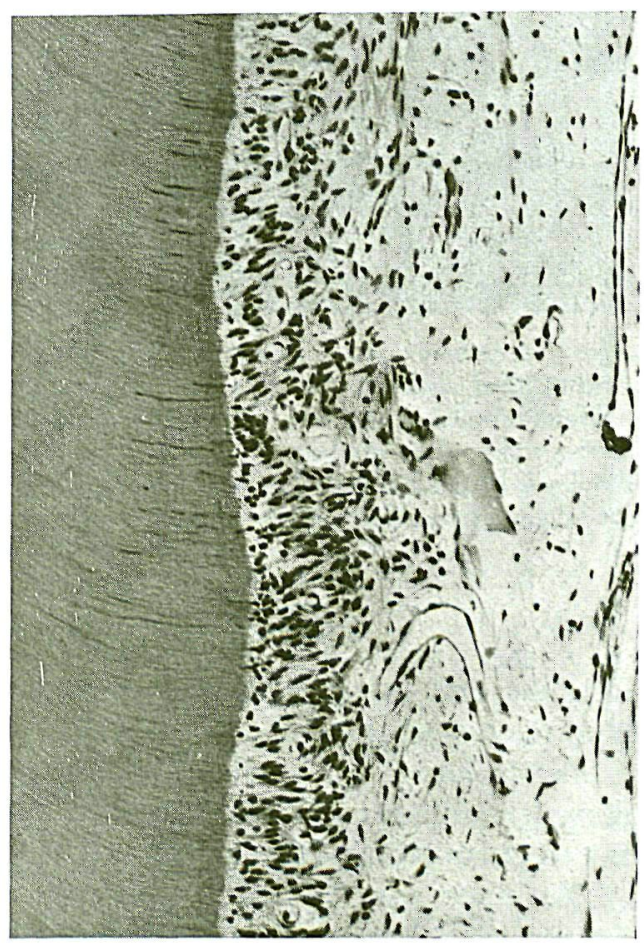

Fig. 3. Grade 2 inflammatory response of dental pulp 3 weeks after amalgam placement. Some cellular contents are present within the dentinal tubules. A mild localized leukocytic infiltration is present in the odontoblastic and subjacent pulpal layer with the remainder of the pulp as normal tissue. Orig. Mag. $100 \times$. 


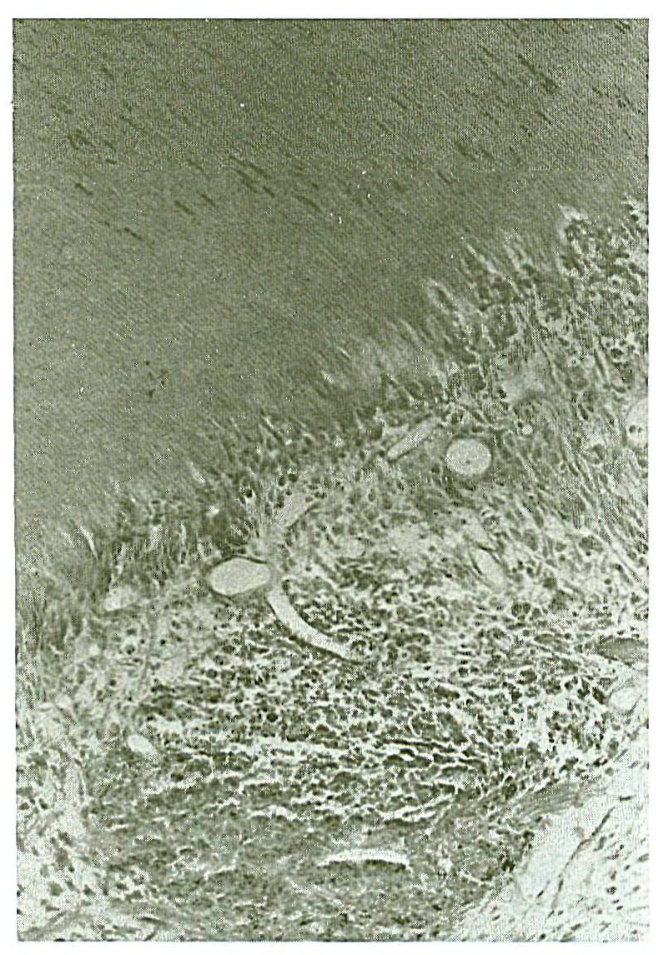

Fig. 4. Grade 4 pulpal abcess below a 3 week placement of Concise ${ }^{\oplus}$. Bacteria are present in the dentinal tubules as well as in the leukocytes of the abcess. The odontoblastic layer below the cut tubules is absent. Small vessels may be seen within the abcess. Brown and Brenn. Orig. Mag. $100 \times$.

from the time of restoration removal were positive on one occasion.

Microbiological examination of the retrieved filter-paper disks from beneath the test materials revealed bacterial growth in 35 $(44 \%)$ of the samples. Thirty cultures contained two or more organisms. The number of Colony Forming Units (CFU) per filter varied from $<100$ (no detectable growth) to $8.37 \times$ $10^{5}\left(\overline{\mathrm{x}}=6.37 \times 10^{4}\right)$. Gram-positive as well as Gram-negative anaerobic cocci and rods of different morphological forms and colonial appearance were identified. Black pigmented bacteroides were recovered from 5 samples and $F$. nucleatum observed in 12 samples.

The growth of bacteria on the retrieved disks depended on the type of restoration used ( $p<0.01$, Tables 1,2). None of the filter-paper disks beneath the ZOE fillings displayed bacterial growth (mean ${ }^{10} \mathrm{log}$ value $=2.0$ ), whereas, all recovered from beneath the silicate cement fillings (mean ${ }^{10} \mathrm{log}$ value $=4.9$ ) and beneath the eight-week amalgam fillings (mean ${ }^{10} \log$ value $=4,1$ ), exhibited bacterial growth. The frequency of bacteria in amalgam, composite and guttapercha fillings was $70 \%, 36 \%$, and $33 \%$, respectively, for the combined $2 / 3$-week and 8 -week periods.

The filters beneath the silicate restorations had significantly higher bacterial counts than those beneath any other restorative material except the amalgam values at 8 weeks (Table 2). Time had little effect on bacterial counts except in the case of the amalgam fillings, where there was a significant increase in the 8 -week values.

Histolological analysis. All pulps examined showed evidence of retained tissue vitality and no extensive tissue breakdown (Table 3 ). When present, inflammation was generally of a mild nature (Grades 2,3) and the inflammatory cell response was Grade 4 in 9 of 79 examined teeth (Fig. 4). Dense accumulation of PMN's was seen only in the 2/3-week test specimens.

ZOE restoration presented a significantly lower degree of infiltration (Table 2), with only two specimens showing Grade 2 inflammatory cell response. Conversely, all silicate cement restorations showed varying degrees of inflammation in the pulp area adjacent to the test cavity. Composite resin and guttapercha treatment permitted all categories of inflammatory-cell reaction. Amalgam-filled teeth presented more Grade 3/4 responses (seven of eight) at 8 weeks than at $2-3$ weeks (3 of 8 teeth). 
Table 2.

Dental materials.

Amalgam Composite Guttapercha Silicate ZOE Significance resin ANOVA*

Log Total Count

2-3 Wks.

8 Wks.

2.85

$4.1^{\mathrm{a}}$

$3.3^{b}$

2.6

2.9

2.6

$\frac{5.3^{\mathrm{c}}}{4.5^{\mathrm{n}}}$

$2.0^{\mathrm{b}}$

$<.01$

Inflammatory Cell Response

2-3 Wks.

$8 \mathrm{Wks}$.

2.2

2.8

2.5

3.2

2.0

$<.01$

Reparative Dentin Formation 2-3 Wks.

$8 \mathrm{Wks}$.

a. significantly higher than composite, guttapercha, and ZOE.

b. values in horizontal row significantly different.

c. value in box are significantly different from other values in horizontal row.

d. significantly lower than amalgam and composite.

e. significantly lower than amalgam, composite, and silicate.

The Sheffe test analysis of effect of dental materials upon the levels of bacteria on the filter-paper disk, degree of inflammatory cell response and reparative dentin formation.

* Analysis of variance.

Reparative dentin formation was observed in most specimens and was more pronounced at 8 weeks than 2-3 weeks (Table 2), ZOErestored teeth showed less reparative dentin than other teeth $(\mathrm{p}<0.05)$ with 12 of 19 ZOE-sealed exhibiting no sign of reparative dentin formation. The occurrence of reparative dentin accompanied inflammatory cell infiltration $(p<0.001)$ except with abscess formation, where no reparative dentin formed.

The thickness of the remaining dentin wall separating the cavity and the pulp ranged from $0.05 \mathrm{~mm}$ to $1.65 \mathrm{~mm}(\overline{\mathrm{x}}=0.60$, standard deviation \pm 0.34$)$. There was no statistical difference in the thickness of the remaining dentin between the test groups. There was no correlation between residual dentin thickness and the occurrence of reparative dentin and inflammatory cell infiltration.

Bacteria were detected within the dentinal tubules of teeth restored with amalgam, com-
Table 3.

\begin{tabular}{|c|c|c|c|c|c|c|c|c|}
\hline \multirow[b]{2}{*}{ Grade } & \multicolumn{4}{|c|}{$\begin{array}{l}\text { Inflammatory } \\
2-3 \text { Weeks }\end{array}$} & \multicolumn{4}{|c|}{$\begin{array}{c}\text { Cell Response } \\
8 \text { Weeks }\end{array}$} \\
\hline & 1 & 2 & 3 & 4 & 1 & 2 & 3 & 4 \\
\hline $\begin{array}{l}\text { Composite resin } \\
(0.58 \pm 0.39)\end{array}$ & 6 & 0 & 2 & 3 & 1 & 2 & 3 & 2 \\
\hline $\begin{array}{l}\text { Amalgam } \\
(0.70 \pm 0.38)\end{array}$ & 1 & 4 & 3 & 0 & 1 & 0 & 6 & 1 \\
\hline $\begin{array}{l}\text { Silicate } \\
(0.79 \pm 0.30)\end{array}$ & 0 & 1 & 3 & 2 & 0 & 3 & 3 & 0 \\
\hline $\begin{array}{l}\text { Guttapercha } \\
(0.54 \pm 0.33)\end{array}$ & 2 & 0 & 3 & 1 & 3 & 2 & 2 & 0 \\
\hline $\begin{array}{l}\text { Zinc oxide-eugen } \\
(0.55 \pm 0.40)\end{array}$ & ol & 0 & 0 & 0 & 7 & 2 & 0 & 0 \\
\hline
\end{tabular}

Inflammatory-cell response in the pulp between teeth. Classification is made according to an arbitrary scale graded $1-4$. Figures within parentheses represent mean value and standard deviation of the remaining dentin separating the cavity preparation and the pulp as measured along the dentinal tubules. 
Table 4.

\begin{tabular}{|c|c|c|c|c|c|c|c|}
\hline \multirow{3}{*}{$\begin{array}{l}\text { Bacterial Growth } \\
\text { CFU/ml RTF* }\end{array}$} & & \multicolumn{6}{|c|}{ Comparison of Bacteria and Inflammatory Responses } \\
\hline & & \multicolumn{3}{|c|}{$2-3$ weeks } & \multicolumn{3}{|c|}{8 weeks } \\
\hline & & $<10^{2}$ & $10^{2}-10^{4}$ & $>10^{4}$ & $<10^{2}$ & $10^{2}-10^{4}$ & $>10^{4}$ \\
\hline & 1 & 19 & 0 & 0 & 11 & 0 & 1 \\
\hline Inflammatory cell & 2 & 2 & 1 & 2 & 6 & 1 & 2 \\
\hline Responses & 3 & 4 & 3 & 4 & 2 & 4 & 8 \\
\hline & 4 & 0 & 0 & 6 & 0 & 1 & 2 \\
\hline
\end{tabular}

The various grades of inflammatory cells plotted against bacterial count. Numbers represent teeth within each category.

$*$ RTF $=$ transport medium (Syed \& Loesche 1972).

posite, guttapercha, and silicate cement. However, no bacteria were observed in tubules underneath zinc oxide eugenol. The intensity of the staining reactions varied from small aggregates of bacteria in a few testcavity, tissue sections to extensive bacterial invasion of the dentinal tubules and the dental pulp cavity (Fig. 4). Cavities not rinsed with EDTA, had bacteria only on the cavity floor. This occurred in 11 of 24 teeth in one monkey, the remaining 13 teeth showed no positive staining in the test cavity.
Correlation of microbiological and histological data. A strong statistical relationship ( $\mathrm{p}<$ 0.001 Chi square) existed between the inflammatory cell response and the bacterial levels of the recovered filter disks (Table 4). Thirty of 31 non-inflamed pulps had no detectable bacterial growth, however 8 of 9 pulps with severe infiltration had high bacterial levels $\left(>10^{4} \mathrm{CFU}\right)$. The statistical correlation between incidence of bacteria and inflammatory pulp-status was common to both time periods.

Table 5 .

Ranking of restorative materials correlative to bacterial leakage and pulpal response.

\begin{tabular}{|c|c|c|c|c|c|c|}
\hline \multirow[t]{2}{*}{ Dental Material } & \multicolumn{2}{|c|}{$\begin{array}{c}\text { Bacterial Counts } \\
\log 10\end{array}$} & \multicolumn{2}{|c|}{$\begin{array}{l}\text { Inflammatory } \\
\text { Cell Response }\end{array}$} & \multicolumn{2}{|c|}{$\begin{array}{c}\text { Reparative } \\
\text { Dentin Formation }\end{array}$} \\
\hline & $3 \mathrm{wks}$ & 8 wks & $3 \mathrm{wks}$ & $8 \mathrm{wks}$ & $3 \mathrm{wks}$ & $8 \mathrm{wks}$ \\
\hline ZOE & 13 & 10 & 10 & 9 & 12 & 13 \\
\hline Guttapercha & 19 & 14 & 24 & 15 & 25 & 23 \\
\hline Composite resin & 22 & 15 & 21 & 25 & 23 & 20 \\
\hline Amalgam & 18 & 29 & 23 & 26 & 22 & 22 \\
\hline Silicate & 36 & 30 & 31 & 22 & 24 & 18 \\
\hline Kruskal Wallis & 0.007 & 0.001 & 0.007 & 0.005 & NS & NS \\
\hline
\end{tabular}


The filling materials were compared for bacterial leakage and pulpal response.

The silicate cement had significantly higher bacterial counts than other materials and this was associated with pulpal inflammatory cell responses. ZOE had significantly lower bacterial counts and inflammation than the other dental materials. Amalgam samples showed a higher degree of bacterial leakage after 8 weeks than after 3 weeks. None of the other materials showed a similar time-related increase of bacterial count.

The non-parametric Kruskal-Wallis test permitted analysis by degree of bacterial leakage and pulpal response (Table 5). ZOE fillings permitted the least bacterial leakage and silicates the most. Guttapercha, composite, and amalgam fillings were intermediate although the margin of difference between them was small. The analysis revealed significant differences between materials (Table 5).

\section{Discussion}

Bacteria were frequently recovered beneath silicate cement, amalgam, composite resin and guttapercha fillings in monkeys' teeth for periods of 2-3 weeks and 8 weeks. This confirms and extends other investigative data (Brännström 1981, Brännström \& Nyborg 1971, 1973, 1974, Brännström \& Vojinovic 1976, Hansen \& Bruun 1971, Dickey et al. 1974, Qvist 1975, Mejàre et al. 1979), showing that dental restorative materials in general have a poor capacity to prevent bacterial contamination of subjacent cavity walls. The bacterial samples retrieved from ZOE fillings, however, yielded no growth, which accords with Möller (1966), that ZOE cement, as a temporary seal of access openings in endodontic therapy, effectively prevents bacterial contamination of the pulpal chamber.

The presence and the composition of the underlying bacteria were analyzed by cultur- ing filterpaper disks placed in the cavity base prior to insertion of the test material. This differs from the technique used by Mejàre et al. (1979) who isolated bacteria from cavities beneath composite resin. After extraction the tooth crown was split through the test cavity, bacterial samples were taken from one half, the other being used for microscopic examination. This provided excellent correlation between bacterial cultivation and staining, but did not allow proper evaluation of the pulpal histopathology.

Other studies to correlate the presence of bacteria on and in dentin with the histological status of the pulp, have employed special sectional staining (Brännström 1971, Brännström \& Nyborg 1971, 1973, 1974, Brännström \& Vojinovic 1976, Hansen \& Bruun 1971, Dickey et al. 1974, Qvist 1975). However, there are several shortcomings with histobacteriologic techniques. The present study and that by Mejàre et al. (1979), found Gramnegative organisms frequently colonized the cavity walls and such organisms may not be readily detected by staining.

Other important limitations are the inability of bacterial staining to identify various types of micro-organisms, and the potential loss of bacteria at the filling/dentin interface, during processing (Mjör 1977a, b). Omission of EDTA pretreatment in one animal produced a lack of correlation between the bacterial staining and the microbiological analysis results. The removal of the smear layer by EDTA (Leidahl \& Eriksen 1979) may have allowed the bacteria to penetrate the dentin tubules, whereas, in non-EDTA treated cavities, bacteria could have been trapped in the smear layer and/or possibly lost during histological processing.

The problems of identifying and localizing test-cavity bacteria seem to have been effectively controlled by our filter-paper technique. The dilution sequence was selected to permit detection of as few as 100 bacterial 
cells per filter, and the removal transport technique ensured that any bacteria present would be cultured and characterized.

The results showed no bacterial leakage with ZOE fillings and subjacent pulp structures were normal. The high bacterial levels beneath silicate fillings were associated in all cases with varying degrees of pulpal inflammation. Amalgam fillings exhibited low levels of contamination after 3 weeks, but at 8 weeks considerable levels of bacteria were recovered from 6 of 8 teeth (Table 1), indicating that time was necessary for bacterial invasion of the cavity, and further suggesting that marginal sealing with corrosion products was ineffective by 8 weeks, for the particular amalgam used.

Several factors suggest the source of infection was not bacteria trapped on the cavity floor, but rather, leakage from the oral environment at the cavity margin: (1) a strict aseptic technique during all operative procedures; (2) cavities cleansed with EDTA; (3) controls prior to filling indicated no contamination in 33 of 35 samples with subsequent bacterial growth on the filter-paper; (4) bacteria isolated were both Gram-positive and Gram-negative anaerobic, cocci and rods. It seems unlikely that Gram-negative anaerobes, if contaminating the cavity floor at the time of filling, would have much chance to survive and multiply in a poor nutritional supply area, while exposed to host defense factors in the dentinal fluid. These organisms probably penetrated after restoration, and the formation, on the external filling surfaces, of the aged dental plaque, of which they are typical (Theilade \& Theilade 1976). That solitary micro-organisms, contaminating the cavity at the time of preparation, may not survive, is substantiated by the observation that of 8 positive sterility controls only 2 displayed bacterial growth on the retrieved filter disks.

Mejàre et al. (1979) isolated bacteria under six of seven composite resin fillings, their high frequency may be explained by not acidetching the cavity margins before filling. Going (1979) reported that, after acid-etching cavity margins, an application of low-viscosity bonding-resin improved margin at adaptation of resin composites. Despite these precautions, several teeth in the present study, filled with such composites exhibited bacteria in the test cavity. This concurs with Qvist (1980) who found 14 of 43 acid pre-etched, composite resin fillings in human third molars, showed poor marginal adaption after four months, with cavity-floor bacterial growth subjacent to several restorations.

The data from this investigation suggests that marginal integrity of dental restorative materials is important for the maintenance of pulpal health. Grades 3 and 4 inflammatory cell infiltration were seen in conjunction with bacterial growth. In several instances bacterial accumulation had resulted in localized abscess formation in the subjacent pulpal tissue at the 2/3-week observation. Reparative dentin accompanied the inflammatory infiltrates at the 8-week observation, demonstrating the defensive potential of pulpal tissue in response to bacterial irritation (Bergenholtz 1981). Where there were no demonstrable bacteria beneath the test material, the pulpal tissue was usually unaffected. This fully accords with observations by Brännström and colleagues (Brännström 1971, Brännström \& Nyborg 1971, 1973, 1974, Brännström \& Vojinovic 1976), that sub-restoration, bacterial accumulation on freshly cut dentin is associated with inflammatory changes in the pulpal tissue. It should be recognized that absence of stainable or cultivable bacteria on the dentin floor may not preclude bacterial influences on the pulp. Bacterial products from saliva, dental plaque, or tooth-surface deposits may, without simultaneous bacterial invasion, gain access to the exposed dentinal tubules through marginal gaps. This could explain why the pulp of some of the guttapercha-filled teeth 
was inflamed despite the absence of bacteria in the cavity.

\section{Conclusions}

1. Oral environmental bacteria may invade a cavity via gaps at the margins of dental restorations, resulting in inflammatory alteration of subjacent pulpal tissue.

2. Confirmation of bacterial leakage around dental restorations should be assessed both histopathologically, and bacteriologically by culture.

3. The quantitative cultivation methods used, showed the highest degree of leakage with silicate fillings, intermediate levels with guttapercha, composite resin and amalgam, and no leakage at all with ZOE.

4. Tests for pulpal biocompatibility of dental restorative materials must always take account of the influence of contaminating bacteria.

\section{Acknowledgements}

The authors wish to thank Messrs. John A. Baker and Ron Earnest for their technical assistance, Mrs. Eloise McIvor for proof reading the manuscript and Mrs. Millie Wadsworth for typing the manuscript.

This project was supported by oral Histology Research Fund No. 333790, and by The University of Michigan School of Dentistry, Biomedical Research Grant No. 019155.

\section{References}

Recommended Standard Practices for Biological and Clinical Evaluations in Guide to Dental Materials and Devices, 8th edn., pp. 200-210. American National Standards Committee MD 156 for Dental Materials and Devices (1978), ADA.
Aranki, A., Syed, S. A., Kennedy, E. B. \& Freter, R. (1969) Isolation of Anaerobic Bacteria from Human Gingiva and Mouse Cecum by Means of Simplified Anaerobic Glove Box Procedure, Appl. Microbiol 17, 568-576.

Bergenholtz, G. (1977) Effect of Bacterial Products on Inflammatory Reactions in the Dental Pulp, Scand J Dent Res 85, 122-129.

Bergenholtz, G. (1981) Inflammatory Response of the Dental Pulp to Bacterial Irritation. $J$ Endod 7, 100-104.

Bergenholtz, G., Ahlstedt, S. and Lindhe, J. (1977) Experimental Pulpitis in Immunized Monkeys. Scand J Dent Res 85, 396-406.

Bergenholtz, G. \& Lindhe, J. (1975) Effect of Soluble Plaque Factors on Inflammatory Reactions in the Dental Pulp. Scand $J$ Dent Res 83, 153-158.

Bergenholtz, G. \& Warvinge, J. (1982) Migration of Leukocytes in the Dental Pulp in Response to Plaque Bacteria. Accepted for publication in Scand J Dental Res.

Brännström, M. (1971) Dentin and Pulp in Restorative Dentistry. Dental Therapeutics $A B$, Nacka, Sweden.

Brännström, M. \& Nyborg, H. (1971) The Presence of Bacteria in Cavities Filled with Silicate Cement and Composite Resin Materials. Swed Dent $J$ 64, 149-155.

Brännström, M. \& Nyborg, H. (1973) Cavity Treatment with a Microbicidal Fluoride Solution: Growth of Bacteria and Effect on the Pulp. $J$ Prosthet Dent 30, 303-310.

Brännström, M. \& Nyborg, H. (1974) Bacterial Growth and Pulpal Changes Under Inlays Cemented with Zinc Phosphate Cement and Epoxylite CBA 9080. J Prosthet Dent 31, $556-565$.

Brännström, M. \& Vojinovic, O. (1976) Response of the Dental Pulp to Invasion of Bacteria Around Three Filling Materials. J Dent Child 43, 15-21.

Brown, J. H. \& Brenn, L. (1931) A Method for the Differential Staining of Gram Positive and Gram Negative Bacteria in Tissue Sections. In: Bull, Johns Hopkins Hosp. 48, 69-73.

Cox, C. F., Heys, D. R. \& Heys, R. J. (1977) A Gravity Perfusion Technique for Lab Animals. Lab Animal 6, 18-22.

Dickey, D. M., El-Kafrawy, A. H. and Mitchell, D. F. (1974) Clinical and Microscopic Pulp Response to a Composite Restorative Material. $J$ Am Dent Assoc 88, 108-113. 
Frank, R. M. (1976) Reactions of Dentin and Pulp to Drugs and Restorative Materials, J Dent Res 54 (Special Issue B), 176-187.

Going, R. E. (1979) Reducing Marginal Leakage: a Review of Materials and Techniques, $J$ Am Dent Assoc 99, 646-651.

Hansen, H. P. \& Bruun, C. (1971) Long-term Pulp Reaction to Silicate Cement With an Intradental Control, Scand J Dent Res 79, 422-429.

Leidahl, T. I. \& Eriksen, H. M. (1979) A Scanning Electron Microscopic Study of the Effect of Various Cleansing Agents on Cavity Walls in vitro. Scand J Dent Res 87, 443-449.

Loesche, W. J. \& Straffon, L. H. (1979) Longitudinal Investigation of the Role of Streptococcus Mutans in Human Fissure Decay. Infect \& Immun 26 (2), 498-507.

Mejàre, B., Mejàre, I. \& Edwardsson, S. (1979) Bacteria Beneath Composite Restorations - a Culturing and Histobacteriological Study. $A$ Odontol Scand 37, 267-275.

Mjör, I. A. (1977a) Histologic Demonstration of Bacteria Subjacent to Dental Restorations. Scand J Dent Res 85, 169-174.

Mjör, I. A. (1974b) Bacteria in Experimentally Infected Cavity Preparations, Scand J Dent Res 85, 599-605.
Möller, A. J. R. (1966) Microbiological Examination of Root Canals and Periapical Tissues of Human Teeth, Thesis: Odontol Tidskr 74, $1-380$.

Qvist, V. (1975) Pulp Reactions in Human Teeth to Tooth Colored Filling Materials. Scand J Dent Res 88, 54-66.

Qvist, V. (1980) Correlation Between Marginal Adaptation of Composite Resin Restorations and Bacterial Growth in Cavities, J Dent Res 88, 296-300.

Syed, S. A. \& Loesche, W. J. (1972) Survival of Human Dental Plaque Flora in Various Transport Media. Appl Microbiol 24, 638-644.

Theilade, E. \& Theilade, J. (1976) Role of Plaque in the Etiology of Periodontal Disease and Caries. Oral Sci Rev 9, 23-63.

Charles F. Cox

5213 School of Dentistry

The University of Michigan

Ann Arbor,

Michigan 48109

U.S.A. 
This document is a scanned copy of a printed document. No warranty is given about the accuracy of the copy. Users should refer to the original published version of the material. 